\title{
REGIMENTED ISLAMOPHOBIA:
}

\section{ISLAM, STATE, AND GOVERNMENTALITY IN INDONESIA}

\author{
Syaifudin Zuhri \\ Universitas Islam Negeri Sayyid Ali Rahmatullah Tulungagung \\ syaifudinzuhri@yahoo.com
}

\begin{abstract}
This article discusses the arts of governing Islam in Indonesia, a majority Muslim country, which is neither secular nor Islamic. It tries to explain how the premise of governmentality is modelled into the state structure and politics. Rather than seeing Islamophobia as a cultural practice, the article argues that Islamophobia develops partly because of power relations between the ruler and the ruled, or as I call it "regimented Islamophobia". It is the fear of "Islamic threats" - whether real or imagined - that is deemed as a potent challenge to regimes' power and authority. While the notion of majority-minority relation remains essential to analyse the forms of Islamophobia, this article offers a new insight of how political regimes exercise "governmentality practices" or the arts of governing Islam and controlling Muslim aspirations. This practice of governmentality is a key strategy to pacify Islam during the colonial and postcolonial Indonesia. As far as Indonesian political history is concerned, this governmentality practice is old wine in a new bottle; it is the technique Dutch colonial government and the regimes following the Indonesian independence have exercised for subjugating Islam and controlling aspirations of its believers.
\end{abstract}

Keywords: Islam, Governmentality, Affective Governance, Moderasi Beragama. 


\section{A. Introduction}

Islamophobia is a rapidly growing sentiment in the West and manifests through attitudes and behaviours of individuals as well as policies and practices of organisations and institutions. The Australian Psychological Society (APS) defines phobia as a feel of discomfort and anxiety. It is an extreme fear or dislike of a particular thing or situation, especially one that is not reasonable. At a sociological level, phobia may transform into 'culture of fear' (Tudor, 2008). Thus, in a simple sense, Islamophobia refers to the xenophobic perception towards Islam and Muslim societies. It is a feeling of fear, hatred, and hostility toward Islam and Muslims resulting in bias, discrimination, marginalisation towards and exclusion of Muslims from the social, political, and civic lives. Islamophobia suggests the existence of unreasonable fear of Islam and Muslims (Zimmerman, 2008).

Islamophobia is a global phenomenon (Morgan \& Poynting, 2010), which flourishes in different contexts and collides with various forms of ideological practices. In Western countries, socio-economic and political factors, such as a violent image of Islam, threats of Islam to Western civilization, terrorism, to competition to winning scarce economic resources and the rising number of Muslim population in Western countries as well as the great influx of immigrants from Muslim countries, contribute to the rise of "feeling threatened" and fear of Islam and Muslim (Bleich, 2012). In Myanmar, where Buddhism is the dominant religious group, Islamophobia leads to discrimination towards Rohingya Muslims framed as the other "race" within Buddhist society (M. N. bin M. Osman, 2017). In the Muslim-majority state 
Malaysia, the confluence of race and religion has resulted in increasing Islamophobic attitudes expressed against Malaysian Muslims (M. N. Osman, 2019). For Faisal Devji, the term Islamophobia was coined during the 1990s, referring neither to labour, as with anti-Black racism, nor capital, as with antisemitism, but a global arena without a politics of its own. Islamophobia has not supplanted its racist predecessors, but energised them in a context where nation states seem unable to display political mastery against non-state forces, whether environmental, economic or civilizational (Devji, 2020). It is a long-durée form of Western cultural racism rooted in the expansion of Western capitalism and colonialism (Ramón Grosfoguel \& Mielants, 2006). Islamophobia does not only exist in the labor market, education and global war against terror; it is indeed "the epistemological battleground about the definition of the priorities" (Ramón Grosfoguel \& Mielants, 2006, p. 11)". In many Western countries, Islamophobia is a 'phobia' of multiculturalism and stems from the defense and resistance against the possible effects of multicultural contacts (Marranci, 2004).

However, the dominant studies on Islamophobia particularly focus on Muslim-minority contexts, such as in Western states and non-Muslim societies (Ciftci, 2012; Helbling, 2012). The relationship between the majority and minority groups, mainly in Western countries, is particularly maintained as a conducive environment for Islamophobia to flourish and, for many observers, Islamophobia would therefore be unlikely to develop within Muslim societies. Nevertheless, for sociologists Enes Bayrakh and Farid Hafez, Islamophobia is an ever-present phenomenon and could 
grow in indifferent contexts, including within Muslimmajority societies. Widening the debates on Islamophobia within Muslim societies, a neglected issue within academia, Bayrakh and Hafez argue that Islamophobia should not only be analysed through the lens of majority-minority relationship, but also in terms of power relations, between the powerful and the powerless (Bayraklı \& Hafez, 2019). Ramón Grosfoguel (2006, p. 3) further maintains that Islamophobia should be understood as an epiphenomenon accumulation of capital on a world-scale and is indeed a longstanding global cultural racism which is still alive in the world today.

This article, on the other hand, attempts to problematise the relation of Islam and state through the lens of Islamophobia in colonial and post-colonial Indonesia, where the majority of its population are Muslim. It partly contributes to the discussion on secularism in a country which is neither secular nor Islamic by looking at of how the state "puts into play different structures of ambition and fear" (Asad, 2003, p. 8). To do so, the article historically discusses various forms of Islamophobia and how power relations affect "threats of Islam"-whether real or imagined-in the largest Muslim country in the world. Importantly, the article also contributes to the discussion on the place of cultural identity in the global South. As Ramón Grosfoguel (2011, p. 14) indicates, studies on coloniality and post-coloniality emerge from the global North and mirrors European centrism. The global South develops its particular "colonial power matrix" as a result of different "colonial situations" (Grosfoguel, 2011, p. 14).

This article will look closely at the colonial and postcolonial Indonesian political history and poses questions of 
how the fear of Islam has been negotiated through the state politics during colonial and post-colonial Indonesian regimes, what the impacts of the Dutch colonial presence to postindependence Indonesia are, and how regimes following the independence translate the fear of Islam into state politics. This article further argues that Islamophobia in a Muslim-majority society, i.e., in Indonesia, develops particularly because of constant negotiations among competing ideologies-between the secular state ideology and Islamic aspiration, the need to protect political stability and to deepen statehood loyalty and, at the same time, the centrality of Islam in the state-making in order to ensure and justify governability of Muslims. In Indonesian politics, although the Five Principles (Pancasila) reserves as the ideological bridge of the secular ideology and Islam, this middle-ground seems to overlook the emergence of what I call "regimented Islamophobia." Regimented Islamophobia, as this article argues, stems from political regimes trying to harvest political supports from Muslims to control their aims and to avert unwanted interpretations of Islam and Muslims' aspirations. To do so, political regimes exercise the so-called governmentality practices or the acts of governing Islam by promoting the 'correct' Islamic interpretations following certain procedures and conforming Muslims' aspirations to the officially legitimate standard.

\section{B. Governing Islam: Looking at Indonesia's Past}

In the mid- $16^{\text {th }}$ century, Muslim traders from Indian ocean world introduced Islam in Indonesian archipelago and, during the course of later centuries, major kingdoms in Java adopted Islam as the religion of the palace. The biggest 
Javanese Islamic court was the $17^{\text {th }}$ century Mataram sultanate with the political power reaching outside the island. In the $19^{\text {th }}$ century, many courts in the western part of the archipelago, particularly on the islands of Java and Sumatra, approved Islam the official religion, whereas in the eastern part, the Dutch had successfully converted a significant number of the populations into Christianity. The conversion left unprecedented social changes within the society by fostering conflicts between the adherents of the local religion and the new one. In addition, Islam had to compete with Christianity, as the Dutch colonial government sponsored the massive expansion of Christianity challenging Muslim missionary activities. Furthermore, the Dutch colonial government perceived Islam as a perilous ideology spurring social unrest and several rebellions against its authority. The most well-known revolt against the Dutch colonial regime was the five-year Java war (1825-1830), led by the charismatic Muslim and Javanese prince Diponegoro (Carey, 2008). Also, at the end of the $19^{\text {th }}$ century, the Sufi group (tarekat), Qadiriyya, waged a war against the Dutch government in Banten (Kartodirdjo, 1966). Outside Java, particularly in Aceh and other parts in Sumatra, similar cases emerged, where Islam fueled a revolutionary ideology against the Dutch (Dobbin, 1983).

Feeling threatened by Islam, the Dutch colonial government tried to prevent Islam-inspired revolts through the practice of governmentality. Rather than utilizing a confrontative response, the colonial government launched governmentality projects. Governmentality, as French philosopher Michel Foucault argues, is the art of government that is not limited to the official politics of the state alone, but 
also incorporates a wide range of techniques of discipline and controlling objects (Foucault, 1991). The principle of governmentality, based on which the powerful controls the -in this case, Islamic-norms, discourses, and activities of the subjugated, justified the Dutch's attempts to pacify Islam. The colonial government, as David Scoot (1995) argues, uses laws, rules, and other techniques to set condition "so that people, following only their own self-interest, will do as they ought." It also, as Iza Hussin (2016, p. 37) argues, placed "a newly limited domain of Islamic law at the center of the politics of the colonial state". The Dutch colonial government marginalised Islamic law by limiting it down into the domains of ritual, personal status, and family bureaucracy through the establishment of priesterraden (priest-courts, at the moment known as Islamic courts) in 1882 and Kantoor voor Inlandsche zaken (Department for Native Affairs) in 1899. The latter was responsible for supervising and controlling cultural activities of the colonial subjects, mainly Islamic norms and activities. The outstanding Dutch Arabicist and Islamologist Snouck Hurgronje (1857-1936) served as an adviseur of the department in 1899-1906. Mastering Arabic and Islamic literatures and maintaining vast contacts with "Jawi" Muslims living in Mecca (Laffan, 2003, p. 13), Hurgronje delivered advice to the colonial government to circumvent Islamic revolutionary groups and protect Muslim population from inflicting anti-colonial ideologies of Pan-Islamism (Benda, 1958a). The department, along with the Dutch consulate in Jidda, supervised and controlled the traffic of Muslim pilgrimage (hajj), which had been an important hub for the transmission of Islamic revolutionary ideologies to the East 
Indies. The prolific author and hadrami scholar Uthman bin Yahya (1822-1914), later appointed as Hurgronje's assistant in the department, played a key role within the department's project to pacify the anti-Dutch sentiment among Muslims (Kaptein, 2014). In so doing, Uthman condemned the practice of tarekat and issued legal opinions (fatwâ) in favour of the Dutch colonial government. Despite the fact that he participated in the formation of the anti-Dutch Muslim organization Sarekat Islam (established in 1905 as Sarekat Dagang Islam/SDI and later named Sarekat Islam/SI or Islamic Union in 1906), Uthman installed a pacified form of Islam within the organisation and condemned other leaders of SI who conversed a revolutionary ideology against the Dutch, such as the most influential leader of SI Oemar Said Tjokroaminoto (1882-1934).

Although Dutch's governmentality method failed to curb Islamic-inspired revolts in many parts of Indonesia, the new Japanese colonial power during the 1940s maintained governmentality as a way to control Muslim subjects. During the Japanese occupation (1942-1945), the new colonial power further exercised governmentality techniques, but with different aims. In contrast to the Dutch, instead of inciting the fear of Islam, Japan glorified the spirit of Islamic revolts through invoking the doctrine of holy war under the banner of jihad against the colonial Dutch. Japan completely controlled the Islamic organisation Majelis Islam A'la Indonesia/MIAI (the Greater Islamic Council of Indonesia), and trained Muslim militia for wars against the Dutch (Nieuwenhuijze, 1958, pp. 147-157). The colonial Japan translated the jihad doctrine as an alliance with the Japanese soldiers in wars 
against the Dutch -or to revolt against the European colonial power- for the promise of "Kemakmuran Bersama Asia Timur Raya (Greater East Asia Co-Prosperity Sphere)" under the empire of Japan (Aziz, 1963, p. 200). During the Japanese occupation, Islamic mobilisation through joint forces with the Japanese in the 1940s Southeast Asian Pacific War created a reversed political episode, in which the spirit of Islamic revolution resurfaced, in contrast with the decline of Islam under the Dutch colonial government. Moreover, the slogan "Bantoean Japan kepada Islam (a Japan benevolent to Islam)" as an ambiguous Indonesian sentiment during the Japanese occupation initiated a number of policies facilitating the adoption of Islam into Japanese colonial bureaucracy and transferred informal Muslim leaders into significant positions within the new colonial structure (Kobayashi, 2010). These initiatives reflected the political attempts of Japan to attain Muslim support to win the Pacific War while Muslim leaders, on the other hand, saw Japanese policies as a way to expand their influence (Benda, 1958b, p. 110).

In the eve of Indonesia's independence in 1945, the fear of Islam -and secularism- particularly appeared through two ideological factions within the circle of Indonesian leaders, i.e., the secular-nationalists and the Islamists. While the former particularly perceived Islam as a potent threat for the unity of the future independent country and begged for a secular state, the latter demanded a political favouritism for the Muslim majority in Indonesia through the adoption of Islamic law within the state's constitution, if not the establishment of an Islamic state (Ichwan, 2011a). The Islamists importantly perceived the nationalists' agenda as a threat for Indonesian Muslims to 
practice their religion. The division between the two culminated at the eve of the Indonesian independence. On 22 June 1945, Panitia Sembilan, the nine leading Indonesian leaders, worked in concert to draft the future state constitution through Panitia Persiapan Kemerdekaan Indonesia/PPKI, a special committee for the preparation of Indonesian independence established by the Japan. The committee successfully agreed on the second draft of Pancasila, or well-known as Piagam Jakarta, of which the first principle writes "Ketuhanan yang maha Esa dengan kewajiban menjalankan syariah Islam bagi pemelukpemeluknya" (belief in one God with the obligation to abide by Islamic law for adherents of Islam). For the Islamist faction, the seven words dengan kewajiban menjalankan syariah Islam bagi pemeluk-pemeluknya formed as an ideological promise to run the Muslim-majority country based on Islamic law, but the other faction sees otherwise: it is a threat to the unity of the pluralistic Indonesians (Jackson, 1980, p. 9). Nevertheless, on 18 August 1945 , following the objection of non-Muslim political leaders, mainly the Christians, towards the formulation of the state ideology, the PPKI agreed to omit the Piagam Jakarta formula - 'the obligation to abide by Islamic law for adherents of Islam' - from the first principle of Pancasila.

The revision later generated disappointments of the small fraction within Muslim groups who felt that Islam has come under the threat of secularism. President Soekarno was also deemed as antagonistic to Islam for favouring secularism. The friction particularly culminated when the military leader Sekarmadji Maridjan Kartosuwirjo (1905-1962) refused the accord and, together with his Muslim militia, initiated the revolts against the new republic. As with the first Indonesian 
president Soekarno, Kartosuwirjo was the private secretary of Hadji Oemar Said Tjokroaminoto, the leader of the Partai Sarekat Islam Indonesia/PSII (Indonesian Islamic Sarekat Party). Butunlike Soekarno, who justified the ideological fusion between Islam and nationalism, Kartosuwirjo saw Islam and nationalism mutually exclusive ideologies. He grew to prefer "Islamic favouritism" and struggled to establish al-Qur'an and the sunna (the Prophet's tradition) as the constitution and to implement Islamic law as a national law of the new republic. In early 1948, as a response to the withdrawal of Siliwangi division of the Indonesian army from West Java in accordance to the Renville Agreement with the Dutch, Kartosuwirjo led his Hizbullah, a Muslim military unit, and continued his guerrilla war against the Dutch (Bruinessen, 2002; McVey, 1971, p. 138). In March 1948, the unit transformed into Tentara Islam Indonesia/TII (the Islamic Army of Indonesia) and Kartosurwirjo served as its general (Nieuwenhuijze, 1958, p. 168; van Dijk, 1981). Proclaiming Darul Islam/DI (the Indonesian Islamic State) on 7 August 1949 under his leadership, Kartosuwirjo dismissed the Republic of Indonesia under Soekarno (Boland, 1971, p. 57). On 22 October 1950, Kartosuwirjo demanded President Soekarno to abandon both communism and nationalism, declaring al-Qur'an and the sunna as the constitution of the Indonesian Islamic State. In the 1950s, Kartosuwirjo's Darul Islam expanded widely across the archipelago. In South Sulawesi, Abdul Qahhar Mudzakkar (1920-1965) who joined Kartosuwirjo's Darul Islam in 1950 led the rebellion against the republic under Soekarno. On 14 May 1963, Qahhar proclaimed the independence of Republik Persatuan Islam Indonesia/RPII (Islamic Federated Republic 
of Indonesia) with its centre in South Sulawesi and installed himself the "caliph" (Mudzakkar, 1960; Tilhami, 1984, p. 58). In Aceh, an active military officer as well as the leader of Persatuan Ulama-ulama Seluruh Aceh/PUSA (the Union of All Acehnese Ulama) Daud Beureuh joined Kartosuwirjo's Darul Islam on 20 September 1953 on the twin premises: preventing Aceh's absorption into the province of North Sumatra and the failure of the republic to implement Islamic law.

Soekarno's government successfully pacified Darul Islam in Java by capturing its leader, Kartosuwirjo, in June 1962. Kartosuwirjo was sentenced to death and executed three months later. On 3 February 1965, the government killed the caliph of Darul Islam in South Sulawesi Qahhar Mudzakkar in Lasolo (Gonggong, 2004, p. 339). Likewise, Daud Beureuh's movement was finally brought to an end in 1962 through negotiations between the central government and Aceh rebel forces. As a result, Aceh was granted the status daerah istimewa (special region) and the central government promised a broad autonomy in the fields of religion, custom (adat) and education. However, Daud Baureuh's rebellion then inspired Hassan Tiro, who declared Aceh's independence in 1976 (Reid, 2005, p. 341). Although the Indonesian government successfully overpowered these Islamic rebellions, the tension between the Islamic and secular-nationalist factions still prevailed as some attacks by Islamist groups continued, particularly during the 1970 and the 1980s.

Unlike Darul Islam that launched guerrilla wars against the republic, the Islamic party Partai Majelis Syuro Muslimin Indonesia/Masyumi (Council of Indonesian Muslim Association) was the champion for Islamic opposition against 
Soekarno. It struggled for the establishment of an Islamic state democratically and constitutionally, and strongly opposed Soekarno's government (Boland, 1971, p. 43). Since the revision of the first principle of Pancasila, Masyumi had demanded the re-appliance of Piagam Jakarta and was indeed against Soekarno because of his alliance with Partai Komunis Indonesian/PKI (Indonesian Communist Party). The 1949 Prime Minister of Indonesia, Muhammad Natsir, led Masyumi and became the champion in the fights against communism in the 1950s. He was also engaged in a campaign against Sukarno, whom he considered to be in favour of nationalism and secularism instead of Islam. The conflict between Natsir and Soekarno reached its peak after the 1955 election, which placed the PKI in the fourth position, below the Partai Nasionalis Indonesia/PNI (Indonesian Nationalist Party), Masyumi and Nahdlatul Ulama (NU). The tension became increasingly heated after the 1957 regional elections, which placed the PKI in the leading position in areas of East Java. Finally, on 15 February 1958, Natsir and many Indonesian Army officers, who shared the same opinion that Soekarno was a threat to Indonesian democracy and so were antiSoekarno, proclaimed the establishment of the Pemerintahan Revolusioner Republik Indonesia/PRRI (Revolutionary Government of the Indonesian Republic) in Padang, West Sumatera. After Masyumi's involvement in PRRI, in the late 1950s, Soekarno proclaimed Masyumi an illegal party and sent its key leader, Muhammad Natsir, to jail. Natsir was released in the 1960s despite the high state surveillance imposed on his activism after release. 
The idea of establishing an Islamic state vis-à-vis religiously neutral-state had been the key ideological debate during the first two decades of the Indonesian republic. Nevertheless, debates on state and religion relation in postcolonial Indonesia differ from the secularism debates in Western contexts, which tend to define the relationship between the two in extremely antagonistic point of views. Secularism in Indonesia is closely related to granting religion - in this context, Islam - the proper place and scope in state and society, rather than drawing a separation between religion and state. Thus, in the early period after the independence, ideological debates centered on the question of "adaptation scale" of the new republic to Islam, i.e., on Islamic favouritism or "religiously neutral-state", rather than on the notion of explicitly making a secular state (Ichwan, 2011b). The problem of the state constitution and the implementation of Islamic laws for Muslim citizens were crucial debates involving leaders of Islamic favouritism camp and religiously neutral state faction.

Proponents of the Islamic favouritism contested Pancasila, which had become the state's ideology since the independence, bridging a theocratic state - if not an Islamic state - on the one hand and a religiously neutral state on the other. The secular-nationalist camp, however, felt Islam as a threat to the newly established republic. It was through the Piagam Jakarta that Islamic proponents found themselves with strategic political issues to revive the idea of a full adaptation of religion in Indonesian politics, if not to demand for the establishment of an Islamic state. The aim of the debate over the Piagam Jakarta was to ensure the appliance 
of Islamic law, the Shariah, for Indonesian Muslim citizens, a political issue which nationalists, communists, and nonMuslim groups highly contested. The heated debate ended when the 1959 Majelis Konstituante (Constituent Assembly) failed to reach a solution concerning the state ideology and insisted Soekarno to declare his demokrasi terpimpin (guided democracy) (1959-1965), which brought democracy under a full-authority of the President Soekarno and transformed Indonesia into an authoritarian state.

The authoritarian regime of Soekarno later generated a strong opposition from Islamic groups that perceived the regime as a threat to Islam, thus crystallising the demand for a democratic governmental system and regime change. The tension between Soekarno's government and the Muslim groups was exacerbated by the concern about the deepening influence of the PKI at a grassroots level, threatening the authority of the ulama and the army on a local level, and about a possible economic collapse as well as the competition within the Indonesian Army, i.e., between the pro-Islam and the nationalist-cum-communist factions (Jenkins, n.d., pp. 2-3). Altogether, these concerns inflamed an opposition towards President Soekarno, which culminated following the failed coup of the Gerakan 30 September (30 September Movement).

Although the military leader Soeharto may or may not have secretly instigated the coup, he rapidly gained advantages of the ensuing political clash following the failed coup. He encouraged the discourses about the dangers of communism and the communists' plan to kill their enemies through the Gerakan 30 September. Consequently, Soeharto was able to cultivate a "kill or be killed" atmosphere that incited people 
and set them up against communists (Cribb, 2002, p. 552). Between October 1965 and March 1966, as Robert Cribb estimates, 500.000 people, allegedly PKI members, were murdered (Cribb, 2001). Hundreds of Islamic organisations, mainly the Anshar, which is the paramilitary body of Nahdlatul Ulama, as well as local gangsters participated in the genocide. Also, in 1966, students of the youth movement called Generasi 1966 (Generation of 1966) demanded Soekarno to step down from presidency. It is worth mentioning that the Indonesian Army played a crucial role in assembling and igniting the students' protest (Boland, 1971, p. 142). Other important factors contributing to the harsh opposition toward Soekarno's regime were the beginning of the Vietnam War in the late 1960s, the intensification of the Cold war in Southeast Asia (Ricklefs, 2008, pp. 256-269) and outside interventions, especially by the US government, which feared that communism would spread rapidly throughout Southeast Asia. As Benedict Anderson notes, the result of this fear was a series of US initiatives aimed at incorporating Southeast Asian countries within its sphere of influence through creating loyal and authoritarian anti-communist regimes (Anderson, 1998).

Following the fall of Orde Lama (Old Order) under Soekarno in 1966, the Orde Baru (New Order) (1966-1998) government under Soeharto gave first priority to the renewal of the direction of the state after decades of severe economic crises and ideological debates. The Orde Baru launched a developmentalism project (pembangunan) and at the same time banned ideological debates and ruptures for the sake of stabilitas nasional (national stability) to ensure the pembangunan projects. During the 1970-80s, Islam again 
came under a strict surveillance of the state. The government imprisoned many Muslim leaders considered enemies of the state for promoting Islamic ideology, thus contesting the Pancasila. It also obliged all Islamic organisations to accept Pancasila as the sole foundation of the institution, known also as the policy of asas tunggal (the one and only principle). The biggest Muslim organisation Nahdlatul Ulama/NU officially accepted the asas tunggal in 1984, whereas the second largest Muslim organisation Muhammadiyah followed the move in the following year.

The Orde Baru government's fear of Islam was exercised through the regime's antagonism toward political Islam (lslam politik) referring to groups of Muslims who found Islam as an alternative ideology to Pancasila. However, the regime sponsored cultural Islam (islam kultural), i.e., Islam sans politics, and Muslims' aspiration and Islamic interpretation that correspond to the regime's authority and developmentalism policies. During the 1980s, the Orde Baru government launched some initiatives to control Islamic norms and associations and pacified Islamic political aspiration the government perceived threatening. In 1975, it established the Majelis Ulama Indonesia/MUI (Council of Indonesian Ulama), which quickly became a new body to align Muslims' aspiration with the Orde Baru government's developmentalism projects (Mudzhar, 1993). In addition to the MUI, the Orde Baru government also sponsored a Muslim foundation of Yayasan Amal Bakti Muslim Pancasila/ YAMP (Pancasila Muslim Service Foundation) in 1982. The foundation campaigned the state ideology Pancasila as the asas tunggal by initiating Mosque-based activism. In so 
doing, it built hundreds of mosques bearing the symbol of the Pancasila manifested as an ornament on top of the mosque roof with a pentagonal frame enclosing the Arabic word for God 'Allah' (Zuhri, 2016). Importantly, the Orde Baru regime perceived Islam as an ideology not completely integrated with modernity, a residue of modern age, which was framed in a Western-secular point of view. In the 1980s, the government exercised the "surveillance paradigm" (Sadequee, 2018) as an instrument to regulate Muslim ethical life so that it was suitable for the secular/modern world order. In so doing, in the mid-1980s, the Orde Baru prohibited veiling (jilbab) in government offices and in non-religious state (Salim, 2015, p. 139). In 1990, the Orde Baru also established a Muslim association of Ikatan Cendekiawan Muslim Indonesia/ICMI (the Association of Indonesian Muslim Scholars) chaired by Muslim technocrats rather than Muslim scholars/ulama. This government initiative is aimed at cultivating Muslim technocrats or Western-minded Indonesian Muslims.

Despite the several attempts carried out by the Orde Baru regime to control Islamic expression and aspiration, democratic movements that had swept Indonesia since the 1990s led to the devastating political institutions of the Orde Baru regime. The severe economic crisis engulfing Southeast Asia in the mid-1990 further worsened, destabilising the political structure of Orde Baru and crystallising the demand for Soeharto's resignation from his presidency. The fall of the Orde Baru regime in May 1998 gave birth to the era reformasi (reformation era), with which Indonesians again saw the promise of the democratic state and the freedom of public expression as well as political aspirations. However, the 
reformasi had opened a Pandora's box, resulting in organised violence in many parts of Indonesia. At the state level, it further initiated debates on Indonesian form of secularism, thus reviving the old debate of Islam vis-à-vis Pancasila.

\section{Finding the Path: Moderasi Beragama}

Soeharto's resignation from his presidency on 21 May 1998 served as a symbol of hope for Indonesians who wished to build a democratic state. And it pinpointed a new era in Indonesian political history, era reformasi (the reformation era). Along with this political transition towards democracy, several Islamic parties and Islamic paramilitary groups, e.g., Laskar Pembela Islam (the Islamic Defenders' Force), Laskar Jihad (the Jihad Force), and Laskar Mujahidin (the Mujahidin Forces), were founded (Hasan, 2006, pp. 13-20). These groups particularly called for committing jihad in the Moluccas, where reportedly hundreds of Muslims were killed by Christians. The jihad project in the Post-Orde Baru Indonesia, according to Sidel (2007, p. 221), emerged as an expression of anxieties against the backdrop of the failure of Islam in the formal political arena, on the one hand, and the concomitant dissolution of Islam as a unifying force, on the other hand. The radical expressions of Islamic groups during the Post-Orde Baru exemplify political discontent and political strategy in order to elevate Islam as the influential factor - if not the only factor - in the state's politics since the Indonesian independence and after losing the first general election since the reformasi in 1999 (Liddle, 2000, p. 33).

Appealing to the public, some other radical Muslim groups, which Azyumardi Azra called "political Islam," 
demanded a comprehensive implementation of sharia and partly challenged Pancasila (Azra, 2000, pp. xiii-xiv, 2004, p. 138). Within the Indonesian parliament, the old debate about the omitted seven words of Piagam Jakarta came to the fore again, initiated particularly by the Islamist parties Partai Keadilan/PK (the Justice Party) and Partai Bulan Bintang/PBB (the Crescent Star Party). Along with the wave of the institutionalisation of Islam into the state's ideology, small Muslim groups aspired to install sharia law through local regulations (peraturan daerah shariah/Perda Shariah). In other words, the "Islamic turn" following post-reformasi democratisation again highlighted an old issue on the Indonesian form of secularism, i.e., defining the proper place and scope of Islam in state and society, rather than setting a clear separation between religion and state. Thus, the debate centred on how the combination of religion and state is negotiated, i.e., how to set the limits of the division and the inclusion of religion in Indonesia's political sphere, to which I mentioned earlier as "adaptation scale".

Likewise, during the first two decades of the reformasi, Indonesians witnessed an increase in number and frequency of bombings and terrorist attacks, thus inciting the larger scale of 'securitisation' of Islam. In 2003, the government established two leading institutions specialised in counterterrorism operations and deradicalization strategies, e.g., Badan Nasional Penanggulangan Terorisme/BNPT (the National Counterterrorism Agency) - before named Desk Koordinasi Pemberantasan Terorisme - and Datasemen Khusus/Densus 88 (the Special Detachment 88). Whereas the former institution works mainly on 'soft approaches' for 
counter-radicalisation strategies, the Densus 88 is a special force within the Indonesian police force with a particular task in 'hard approaches' of counter-terrorism operations (Taufiqurrohman, 2013). The two official bodies have been successful in pacifying terrorist cells and implementing counter-terrorism strategies. However, the problem of terrorism remains, particularly how to undermine the leaders of the jihadist groups who are capable of controlling their combatants from behind bars, such as Maman Abdurahman and the charismatic Abu Bakar Ba'asyir.

Importantly, along with a greater demand for democracy and threats ofterrorism, Indonesian Muslims have experienced "Islamic-moral turn" where Islam has become more significant to the lives of many Indonesian Muslims. Likewise, a proliferation of Islamic symbols has emerged in the public sphere. Greg Barton (2001, p. 245) calls the phenomenon of the rising Islamic awareness, mainly among the middle-class Indonesian Muslims, as "santrification" referring to an increase in Islamic piety and a stricter adherence to Islamic practices across large sections of the Indonesian society. Along with the wave of santrification following the reformasi, a rise in the number of attacks against non-Muslims and minority Muslim sects, such as Ahmadiyya and other non-orthodox Muslim groups, occurred (Burhani, 2013). For Martin van Bruinessen, in the years following the reformasi, Indonesians witnessed the so-called "conservative turn" in contrast with the longadmired "smiling face of Indonesian Islam" (Bruinessen, 2013). It confirms the "demise of moderate Islam" (Akmaliah, 2020). Like the previous regimes, Post-Orde Baru regimes had to face challenges with the growing Islamic conservatism, 
which in many cases are supported by MUI and hard-liner Islamist groups, particularly the Front Pembela Islam/FPI (Islamic Defender Front) which the Indonesian government dissolved in December 2020.

From the state's point of view, the wave of Islamic conservatism is seen as a political threat to the state and to the religious harmony in Indonesian. And as the counternarrative - among other things - to Islamic conservatism, the state officially launched the project "moderasi beragama" literally translated as "religious moderation". Moderasi beragama is indeed the continuation of the colonial and the postcolonial projects to govern Islam into a political subject matter of "affective governance" (Trein, 2018, p. 1) through appropriating Islamic interpretation in order to define and establish political and religious subjectivities that ensure and justify governability of Muslims. The Kementerian Agama (Indonesian Ministry for Religious Affairs) has been at the forefront of the project. At the eve of his service, the Minister for Religious Affairs Lukman Hakim Saifuddin (2014-2019) officially inaugurated "an official manifesto" on moderasi beragama through the ministry's publication titled Moderasi Beragama. The book highlighted religion related issues and the state, such as pluralistic Indonesians, the state ideology Pancasila, and religion as a solution - rather than a problem for the growing conservatism.

Importantly, the project moderasi beragama aims to strengthen the state ideology, Pancasila. Rather than seeing Islam vis-à-vis Pancasila, moderasi beragama again emphasises the compatibility of Pancasila and Islam, a strategy the regimes before the reformasi had always stressed when 
explaining Pancasila from the light of Islam (Kementerian Agama, 2019, p. 56). The doctrine of nationalism, as this project constructs, is the consensus of Indonesian Muslims that should be maintained and protected from any threat of transnational ideologies. Thus, according to the manifesto of moderasi beragama, Indonesian form of nationalism contradicts Anderson's conception (2006) of "secular-mode of nationalism" which ignores religion. Indonesian form of nationalism is exclusively religious and reverberates what Menchik (2017, p. 67) calls "godly nationalism" - "an imagined community bound by a common, orthodox theism and mobilized through the state in cooperation with religious organizations in society". The current Indonesian government has exercised this godly-nationalism manifesto as a repertoire for disbanding the transnational Islamist movement Hizbut Tahrir Indonesia/HTI in 2017.

In addition to nationalism, through the prologue of the book Moderasi Beragama, Lukman Hakim further elaborates the meaning of moderasi beragama and writes:

Moderasi beragama aims to attune the twocontradictory factions in religiosity. On the one hand, there are believers who extremely believe their faith as the only valid interpretation towards religious texts and excommunicate different interpretations. This faction is usually identified as ultraconservative. On the other hand, there are believers who glorify reasonings while neglecting the purity of the faith and sacrifice their faith for the sake of tolerance toward different religious believers. This latter group is the extreme liberal faction. Both need to be balanced. (Kementerian Agama, 2019, p. 7) 
The above quote clearly tells that, despite targeting Islamic conservatism and instilling godly nationalism, moderasi beragama also resorts as a criticism toward a liberal group activism in Indonesia and calls for the need to attune the two competing Islamic interpretations, i.e., the conservative and the liberal interpretations of Islam. The conservative, as the official document Moderasi Beragama mentions, is a mode of thought that tightly holds a truth claim while neglecting and, in many cases, excommunicating those who have different views and often calls for a full adoption of Islam in Indonesian politics, if not to establish an Islamic state, particularly through the efforts of inserting a reference to Shariah into the Indonesian constitution. The liberal, on the other hand, is a mode of thought that emerges from the supremacy of reason while neglecting the textual dimension of religion (Kementerian Agama, 2019, p. 47). The liberal group activism, tied to the younger generation of Westerneducated Muslims within two biggest Muslim organizations in Indonesia, NU and Muhammadiyah, actively campaign for liberalism, secularism, and pluralism while attacking fellow Muslims who are conservative (Nurdin, 2005). Nevertheless, the conservatives had long gained a strategic momentum to condemn the liberals after MUI issued a fatwa against the liberal group. Through its fatwa in 2005, MUI declared the need to protect Islam and Muslims from 'spilis,' the abbreviation of secularism, pluralism and liberalism (Gillespie, 2007). The abbreviation strongly referred to the disease syphilis, which also reflected the destructive image. The spilis agenda of the liberal group reserved as a "Western disease" that would potentially destroy Indonesia. For many conservative groups, such as FPI and HTI, the fatwa went beyond the condemnation against the liberal group because it was a vindication for their 
agenda to turn Indonesia into an Islamic state or at least as a strategy to install sharia law as the state's constitution (Kersten, 2015, pp. 1-2).

Nevertheless, on the other side of the spectrum, moderasi beragama tries to defy the conservative groups that has gained momentum and followers in the Indonesian religious landscape. Conservative groups have a history of inciting intragroup conflicts within the Indonesian Muslim community with attacks against minority groups, such as AhmadiyyaMuslim. They also exacerbate inter-religious group relations by protesting the place of Indonesian non-Muslims in a Muslimmajority public sphere and demanding Muslim favouritism in the state structure and bureaucracy. The groups often target night clubs, calling for the closure of places they consider sinful and contradictory with Islamic norms.

The most recent trial of moderasi beragama was the Ahok's case in 2017. As often found in Western countries where Islamophobia collides with racial issues (Lauwers, 2019), the Ahok's case incited Islamophobia, particularly among the minority Chinese Indonesian and Christians (Shukri, 2019). Popularly known as Ahok, the Chinese Indonesian and Christian politician Basuki Tjahaya Purnama once served as the vice governor of Jakarta and later as the governor as Joko Widodo was elected president in 2014. Since the beginning, by winning the provincial election in Jakarta, Ahok was a controversial, unfavourable political leader to the eyes of many conservative Muslim groups, mainly the FPI, that had voiced strong opposition for having a non-Muslim leader as early as 2012 when Ahok first took office as the vice governor of Jakarta. The strong opposition emerged on 27 September 2016 when Ahok mentioned in his speech that people should not vote for a candidate based on religious beliefs, criticising 
the notion that Muslims cannot have a non-Muslim as their leader. An edited video of his remarks appeared on social media, quickly went viral, and incited a series of street protests of Muslim groups that accused Ahok of insulting the Qur'an. Conservative Muslim groups stormed the streets of Jakarta, demanding that the government arrest Ahok and send him to trial. The remarkable mass to join the street protests named Gerakan 212 (212 Movement) led by Rizieq Shihab, a Hadhrami-sayyid and the leader of FPI, successfully mobilised a significant number of Muslims, not only from Jakarta, but also from other cities in Java and outside. On 9 May 2017, Ahok was sentenced to two years in prison.

Nevertheless, Ahok's case has reenergised anti-Chinese prejudice and Islamic favouritism within the supposedly nondiscriminatory state based on the five principles of Pancasila, a state that is neither secular nor Islamic. This effect has been an important issue in the 2019 president election, threatening the peaceful coexistence among religious groups in Indonesia. Lukman Hakim, the Minister of Religious Affairs who initiated moderasi beragama - a project which was later adopted as one of the ministry's priority programs - envisioned the project as a panacea for social disintegration and disharmony, particularly as a result of the diversity of ethnicities and religions. This panacea centers on the notion of wasatiyyah (middle or moderate), which strongly opposes religious conservatism on the one hand and religious liberalism on the other hand. At the same time, being wasatiyyah also demands statehood loyalty and obedience (Kementerian Agama, 2019, pp. 16-17).

\section{Conclusion}

Amid the rapidly growing Islamophobia in the West, as this article has demonstrated, culture of fear flourishes in 
different contexts and collides with various forms of ideological practices. In Indonesia, it appears in the form of threats of Islam - whether real or imagined-which develops particularly because of constant negotiations among competing ideologies. In colonial and post-colonial Indonesia, the Dutch, Japan, and post-independence Indonesian regimes have exercised the arts of governing Islam through premises of governmentality. On the one hand, each regime struggles to establish its political power through idioms of Islam. On the other hand, they are worried about the possible threats of Islam as well. The Dutch colonial government and Indonesian regimes are in the same boat when it comes to the politics of the majority Muslim country, in that they apply their own versions of governmentality as a way of controlling Muslims' aspirations, implying that the practice of governmentality is a longstanding method for governing Islam. This technique of subjugating Islam and controlling Muslims' aspirations began with the Dutch and Japanese colonial governments and was continued by the following Indonesian regimes post-independence.

Culture of fear of the colonial and postcolonial regimes roots at the problem of adaptation scale of Islam, the religion of the majority. Rather than the problem of secularism signified by the antagonistic relation between the church and the state as we witnessed in the West, Indonesian politics tells that religion plays major roles in the state-making. Indonesian form of nationalism is exclusively religious and demonstrates "godly nationalism". It has never been secularistic and, therefore, religion is central in the nationbuilding. Colonial and post-colonial regimes have deployed a model of governance with which they appropriated the 'correct' Islamic interpretation and defined valid religious subjectivities that ensure and justify the governability of 
Muslims. In turn, it affects the ways each regime governs 'fears of Islam' and defines the 'legitimate form of Islam' in a certain political period.

Therefore, as this article has also articulated, Islamophobia can occur in majority-Muslim societies. And in case of Indonesia, it exists in a form of "regimented Islamophobia," which is designed and developed by political regimes to win Muslims' hearts, to control their aspirations, and to judge the 'proper' interpretation of Islam in the country, thereby diminishing the presence of other interpretations -often contradictory- of Islam. By governing the interpretation of Islam, the Indonesian government has promoted a statesanctioned form of Islam among the varied interpretations that exist - from the liberal to conservative, if not radical - and it has reinforced its agenda through implementing policies, establishing institutions and designing projects to enhance Muslims' statehood loyalty and obedience. The current Indonesian regime designates moderasi beragama as the official form of Islam criticising both the liberal and conservative interpretations of Islam, while at the same time serving as a tool to strengthen the state's nationalistic goals and the state-making.

\section{REFERENCES}

Akmaliah, W. (2020). The Demise of Moderate Islam: new media, contestation, and reclaiming religious authorities. Indonesian Journal of Islam and Muslim Societies, 10(1), 1-24. https://doi.org/10.18326/ijims.v10i1.1-24

Anderson, B. (1998). From Miracle to Crash. London Review of Books 20, 8, 3-7. https://www.lrb.co.uk/the-paper/ v20/n08/benedict-anderson/from-miracle-to-crash 
Anderson, B. (2006). Imagined Communities: Reflections on the Origin and Spread of Nationalism (Revised ed). Verso.

Asad, T. (2003). Formations of the Secular: Christianity, Islam, Modernity. In Formations of the Secular. Stanford University Press. https://doi. org/10.1515/9780804783095

Aziz, M. A. (1963). Japan's Colonialism and Indonesia. M. Nijhoff.

Azra, A. (2000). Islam di Tengah Arus Transisi Menuju Demokrasi. In A. Mu'in (Ed.), Islam di Tengah Arus Transisi. Kompas.

Azra, A. (2004). Political Islam in Post-Soeharto Indonesia. In V. Hooker \& A. Saikal (Eds.), Islamic Perspectives on the New Millennium (pp. 133-149). ISEAS.

Bayraklı, E., \& Hafez, F. (2019). Introduction. In E. Bayraklı \& F. Hafez (Eds.), Islamophobia in Muslim Majority Societies (pp. 1-4). Routledge.

Benda, H. J. (1958a). Christiaan Snouck Hurgronje and the Foundations of Dutch Islamic Policy in Indonesia. The Journal of Modern History, 30(4), 338-347. https://doi. org/10.1086/238264

Benda, H. J. (1958b). The Crescent and the Rising Sun: Indonesian Islam under the Japanese Occupation, 19421945. W. van Hoeve Ltd.

Bleich, E. (2012). Defining and Researching Islamophobia. Review of Middle East Studies, 46(2), 180-189.

Boland, B. J. (1971). The Struggle of Islam in Modern Indonesia. In The Struggle of Islam in Modern Indonesia. Martinus Nijhof. 
Bruinessen, M. van. (2002). Genealogioes of Islamic radicalism in post-Soeharto Indonesia. South East Asia Research, 10(2), 117-154.

Bruinessen, M. van. (2013). Contemporary Developments in Indonesian Islam: Explaining "Conservative Turn." Institute of Southeast Asian Studies.

Burhani, A. N. (2013). When Muslims are not Muslims: The Ahmadiyya Community and the Discourse on Heresy in Indonesia. In Ph.D Dissertation. University of California, Santa Barbara.

Carey, P. (2008). The Power of Prophecy: Prince Dipanagara and the End of an Old Order in Java, 1785-1855. KITLV Press.

Ciftci, S. (2012). Islamophobia and Threat Perceptions: Explaining Anti-Muslim Sentiment in the West. Journal of Muslim Minority Affairs, 32(3), 293-309. https://doi. org/10.1080/13602004.2012.727291

Cribb, R. (2001). Genocide in Indonesia, 1965-1966. Journal of Genocide Research, 3(2), 219-239. https://doi. org/10.1080/713677655

Cribb, R. (2002). Unresolved problems in the Indonesian killings of 1965-1966. Asian Survey, 42(4), 550-563. https://doi.org/10.1525/as.2002.42.4.550

Devji,F.(2020).FromXinjiang to Germany:howdidIslamophobia become a global phenomenon? The Guardian. https:// www.theguardian.com/commentisfree/2020/mar/27/ xinjiang-germany-islamophobia-global-phenomenon 
Dobbin, C. E. (1983). Islamic Revivalism in a Changing Peasant Economy: Central Sumatra, 1784-1847 (2018th ed.). Routledge.

Foucault, M. (1991). Governmentality. In G. Burchell, C. Gordon, \& P. M. (Peter M. Miller (Eds.), The Foucault Effect: Studies in Governmental Nationality (pp. 87-104). University of Chicago Press.

Gillespie, P. (2007). Current Issues in Indonesian Islam: Analysing the 2005 Council of Indonesian Ulama Fatwa No. 7 Opposing Pluralism, Liberalism and Secularism. Journal of Islamic Studies, 18(2), 202-240. https://doi. org/10.1093/jis/etm001

Gonggong, A. (2004). Abdul Qahhar Mudzakkar: dari Patriot hingga Pemberontak. Ombak.

Grosfoguel, R. (2011). Decolonizing Post-Colonial Studies and Paradigms of Political-Economy: Transmodernity, Decolonial Thinking, and Global Coloniality Journal Issue: TRANSMODERNITY: Journal of Peripheral Cultural Production of the Luso-Hispanic. TRANSMODERNITY: Journal of Peripheral Cultural Production of the LusoHispanic World, School of Social Sciences. http:// escholarship.org/uc/item/21k6t3fq

Hasan, N. (2006). Laskar Jihad: Islam, militancy, and the quest for identity in post-New Order Indonesia. Cornell Southeast Asia Program.

Helbling, M. (2012). Islamophobia in the West: an Introducton. In M. Helbling (Ed.), Islamophobia in the West: Measuring and Explaining Individual Attitudes (pp. 1-18). Routledge. 
Hussin, I. R. (2016). The Politics of Islamic law: Local Elites, Colonial Authority, and the Making of the Muslim State. The University of Chicago Press.

Ichwan, M. N. (2011a). Secularism, Islam and Pancasila: Political Debates on the Basis of the State in Indonesia. Bulletin of the Nanzan Center for Asia and Pacific Studies, 6, 1-43.

Ichwan, M. N. (2011b). Secularism, Islam and Pancasila: Political Debates on the Basis of the State in Indonesia. Bulletin of the Nanzan Center for Asia and Pacific Studies, 6, 1-43. https://www.ic.nanzan-u.ac.jp/ASIAPACIFIC/ documents/110228-0301_Ichwan.pdf

Jackson, K. D. (1980). Traditional authority, Islam, and Rebellion: a Study of Indonesian Political Behavior. University of California Press.

Jenkins, D. (n.d.). Suharto and His generals: Indonesian Military Politics, 1975-1983. Cornell University Press.

Kaptein, N. J. G. (2014). Islam, Colonialism and the Modern Age in the Netherlands East Indies. In Islam, Colonialism and the Modern Age in the Netherlands East Indies. Brill. https://doi.org/10.1163/9789004278707

Kartodirdjo, S. (1966). The Peasants' Revolt of Banten in 1888. In The Peasants' Revolt of Banten in 1888. Brill. https:// doi.org/10.1163/9789004286788

Kementerian Agama. (2019). Moderasi Beragama. Badan Litbang dan Diklat Kementerian Agama RI.

Kersten, C. (2015). Islam in Indonesia: The Contest for Society, Ideas and Values. Hurst. 
Kobayashi, Y. (2010). Islam during the Japanese Occupation. In P. Post (Ed.), The Encyclopedia of Indonesia in the Pacific War (pp. 300-311). Brill. https://doi.org/10.1163/ ej.9789004168664.i-684

Laffan, M. (2003). Islamic Nationhood and Colonial Indonesia: The Umma Below the Winds. RoutledgeCurzon.

Lauwers, A. S. (2019). Is Islamophobia (always) Racism? Critical Philosophy of Race, 7(2), 306-332. https://doi. org/10.5325/CRITPHILRACE.7.2.0306

Liddle, R. W. (2000). Indonesia in 1999: Democracy Restored. Asian Survey, 40(1), 32-42. https://doi. org/10.2307/3021218

Marranci, G. (2004). Multiculturalism, Islam and the clash of civilisations theory: rethinking Islamophobia. Culture and Religion, 5(1), 105-117. https://doi. org/10.1080/0143830042000200373

McVey, R. (1971). The Post-Revolutionary Transformation of the Indonesian Army. Indonesia, 11, 176. https://doi. org/10.2307/3350748

Menchik, J. (2017). Islam and Democracy in Indonesia: Tolerance without liberalism. Cambridge University Press.

Morgan, G., \& Poynting, S. (Eds.). (2010). Global Islamophobia: Muslims and Moral Panic in the West. Routledge.

Mudzakkar, A. Q. (1960). Konsepsi Negara Demokrasi Indonesia: Koreksi Pemikiran Politik Pemerintahan Soekarno. Darul Falah. 
Mudzhar, M. A. (1993). Fatwa-fatwa Majelis Ulama Indonesia : sebuah studi tentang Pemikiran Hukum Islam di Indonesia, 1975-1988. INIS.

Nieuwenhuijze, C. A. O. van. (1958). Aspects of Islam in Postcolonial Indonesia: Five Essays. W. van Hoeve.

Nurdin, A. A. (2005). Islam and State: a Study of the Liberal Islamic Network in Indonesia, 1999-2004. New Zealand Journal of Asian Studies, 7(2), 20-39.

Osman, M. N. (2019). The Confluence of Race and Religion in Understanding Islamophobia in Malaysia. In E. Bayraklı \& F. Hafez (Eds.), Islamophobia in Muslim Majority Societies (pp. 161-174). Routledge.

Osman, M. N. bin M. (2017). Understanding Islamophobia in Asia: The Cases of Myanmar and Malaysia. Islamophobia Studies Jurnal, $X X(\mathrm{X}), 17-36$.

Ramón Grosfoguel, \& Mielants, E. (2006). The Long-Durée Entanglement Between Islamophobia and Racism in the Modern/Colonial Capitalist/Patriarchal World-System: An Introduction. Human Architecture: Journal of the Sociology of Self-Knowledge, V(1), 1-12.

Reid, A. (2005). An Indonesian frontier: Acehnese and other Histories of Sumatra. NUS Press.

Ricklefs, M. C. (2008). A History of Modern Indonesia Since C. 1200. Macmillan.

Sadequee, S. (2018). Surveillance, Secular Law, and the Reconstruction of Islam in the United States. Surveillance \& Society, 16(4), 473-487. https://doi.org/10.24908/ ss.v16i4.6979 
Salim, D. P. (2015). The Transnational and the Local in the Politics of Islam: The Case of West Sumatra, Indonesia. In The Transnational and the Local in the Politics of Islam: The Case of West Sumatra, Indonesia. Springer. https:// doi.org/10.1007/978-3-319-15413-8

Scott, D. (1995). Colonial Governmentality. Social Text, 43, 191. https://doi.org/10.2307/466631

Shukri, S. F. M. (2019). The Perception of Indonesian Youths toward Islamophobia: An Exploratory Study. Islamophobia Studies Journal, 5(1), 61-75. https://doi. org/10.13169/ISLASTUDJ.5.1.0061

Taufiqurrohman, M. (2013). Counterterrorism in Indonesia: Quo Vadis? Counter Terrorist Trends and Analyses, 5(6), 7-10.

Tilhami, M. A. (1984). Darul Islam di Masserengpulu: Studi Tentang Perubahan Sosial dan Keagamaan di Malua, Enrekang, Sulawesi Selatan. Makassar: Pusat latihan dan Penelitian Ilmu-ilmu Sosial, Hassanuddin University.

Trein, L. (2018). Governing the Fear of Islam: Thinking Islamophobia through the Politics of Secular Affect in Historical Debate. ReOrient, 4(1), 44-58.

Tudor, A. (2008). A (Macro) Sociology of Fear?: Http:// Dx.Doi.Org/10.1111/1467-954X.00417, 51(2), 238-256. https://doi.org/10.1111/1467-954X.00417

van Dijk, C. (Kees). (1981). Rebellion under the banner of Islam: the Darul Islam in Indonesia. Martinus Nijhoff The Hague. 
Zimmerman, J. C. (2008). A Review of: "Hillel Schenker and Ziad Abu-Zayyad. Islamophobia and Anti-Semitism ,." Terrorism and Political Violence, 20(3), 454-456. https://doi.org/10.1080/09546550802194775

Zuhri, S. (2016). The Mosque as the Religious Sphere: Looking at the Conflict over the Al Muttaqun Mosque. In N. J. G. Kaptein \& K. van Dijk (Eds.), Islam, Politics and Change The Indonesian Experience after the Fall of Suharto (pp. 79-102). Leiden University Press.

\section{Acknowledgment}

The author would like to thank three anonymous reviewers for their constructive comments and careful reading of the manuscript. Any mistakes remain mine alone. 